\title{
Floorball helyzetének és passzív sportfogyasztásának vizsgálata egy kutatás tükrében
}

\section{Floorball Position and Passive Sports Consumption in the Light of a Study}

\author{
C. PfaU ${ }^{1}$, Gy. N. SZABADOS ${ }^{2}$, K. DoroGI ${ }^{3}$ \\ ${ }^{1}$ Debreceni Egyetem, Gazdaságtudományi Kar, Sportgazdasági- és menedzsment Intézet \\ pfau.christa@econ.unideb.hu \\ ${ }^{2}$ Debreceni Egyetem, Gazdaságtudományi Kar, A Vezetés- és Szervezéstudományi Intézet, Szervezés és \\ Kommunikáció Tanszék, szabados.gyorgy@econ.unideb.hu \\ 3 Debreceni Egyetem, Gazdaságtudományi Kar, Sportgazdasági- és menedzsment Intézet \\ sid19971111@gmail.com
}

\begin{abstract}
Absztrakt. A floorball sportággal kapcsolatos kutatások általában orvostudományhoz kötődnek, más területen kevés elemzés látott napvilágot. Így a tanulmány célja az volt, hogy bemutassuk a floorball sportág helyzetét hazánkban és passzív sport fogyasztók véleményét vizsgáljuk a sportágról. Ezen belül foglalkozunk hazánk versenyrendszerével, a szövetség szervezeti felépítésével és a sport népszerüségével. Primer kutatásunk során a nézők aspektusából, mint passzív fogyasztókat kérdeztük meg egy kérdöíves felmérés során, hogy milyen kapcsolatuk van a floorball sportággal. A kérdőívben kitértünk arra, hogy találkoztak-e már ezzel a sportággal, valamint, hogy láttak-e már, vagy mi vonzotta ki őket a mérkőzésre. Vizsgáltuk a fizetési hajlandóságukat is. Az eredményeket összevetettük a sportág egyik hazai vezetőjének véleményével, amely sok esetben megegyezett az eredményekkel. A kérdőívet 153 fó töltötte ki, melyeknek több mint 95\%-a hallott a sportágról és legnagyobb százalékban már általános iskolában volt lehetôsége ismerkedni a floorballal. A megkérdezettek 65\%-a már látott élőben floorball mérkőzést, amelyet föleg barátaival/ismerôseivel látogatott. Ez a fiatal sportág egyre népszerűbb lehet a fiatalok körében nemcsak kiegészítő sportágként.
\end{abstract}

Abstract. Research and studies done on floorbal is usually associated with medical studies, however the research and analisys of other fields peakd little interest.Thus, the aim of the study was to present the situation of floorball in Hungary and to examine the opinion of passive sports consumers about the sport. Within this we deal with the competition system of our country and the organizational structure of the federation. In our primary research, from a viewer perspective, we were interviewed as passive consumers in a questionnaire survey about their relationship to floorball. In the questionnaire we discussed whether they had ever met this sport and whether they had seen it or what attracted them to the match. We also tested their willingness to pay. The results were compared with the opinion of one of the domestic leaders of the sport, which in many cases agreed with the results. The questionnaire was completed by 153 people, more than 95\% of whom had heard of the sport and most had the opportunity to become familiar with floorball at primary school. 65\% of those surveyed have already seen a live floorball match that they have mostly 
played with friends / acquaintances. This young sport can become more and more popular among young people, not only as a complementary sport.

\section{Bevezetés}

A hivatalos létezésének 30 éve alatt a floorball spontán rekreációs tevékenységeiből az egyik leggyorsabban növekvő szervezett sporttá fejlődött. A floorball vagy másnéven teremhoki a labdás csapatjátékok nagy családjához tartozik. A sportág világszerte növekvő ütemben válik népszerűvé, kifejezetten az iskolákban nemcsak kiegészítő sportágként. A játék hasonlít a gyeplabdára és a jégkorongra, de a kosárlabdával is vannak közös elemei. A floorball játékhoz szükség van műanyag ütőfejes, szénszálas kompozit ütőre és lyukacsos műanyag üreges labdára. Ez a sportág egy sokoldalú csapatsport, ahol sok akció és gyorsan változó helyzetek lépnek fel a másodperc töredéke alatt. Könnyen elérhető, hiszen bármekkora sport területen játszható, csak a játékosok számát kell az elérhető térhez igazítani. A mai kor sportjának tekinthető, amelyet több mint 60 országban űznek világszerte és gyors ütemben válik a holnap sportjává is. A sportág gyorsan helyet talált magának a hazai iskolarendszerben, mivel alapvető kondicionális és koordinációs képeségekkel már lehet játszani. A sportágban megjelenik az esélyegyenlőség, mivel vegyes csapatok is űzhetik még versenyeken is. Az általános és középiskolák mellett számos munkahelyen és speciális érdeklődésű csoportokban is ismertté vált a játék [4]. A sportággal kapcsolatba orvostudomány területén [10] [12] [13] [15] [16] [27] [28] [29] jelent meg több kutatás, más tudományág még kevésbé foglalkozik ezzel a feltörekvő sportággal [28]. A tanulmányban elemezzük a sportág helyzetét és vizsgáljuk a passzív sportfogyasztók véleményét a sportággal kapcsolatban.

\section{Szakirodalmi áttekintés}

\subsection{A floorball története}

A floorball gyökerei számos különböző játékformában fellelhetők Amerikában és Európában is. A 60-as években az Egyesült Államokban már Floorhockey néven megjelent egy hasonló sportág [6]. A minneapolisi műanyaggyár dolgozói olyan játékhoz gyártottak ütőket, amely jellegében a jégkoronghoz hasonlított, de nem kellett hozná tudni korcsolyázni [9]. Hivatalosan a sportág megjelenését, 1981 november 7.-től számoljuk, amikor a svédek létrehozták az első hivatalos országos floorball szövetséget a svédországi Sala városában. Az első hivatalos szabálykönyv is ekkor jelent meg (1983), amely előírta egy speciális palánk alkalmazását a játékterület körül. Ekkortól számítjuk a modern floorball megjelenését, amely elindította a szervezett sporttá válás útján. Egymás után jöttek létre a nemzeti szövetségek Svájcban, Finnországban, Dániában, majd 1989-ben (még Magyar Palánklabda Szövetség néven) hazánkban is. A Nemzetközi Floorball Szövetség (IFF) 1986-ban alakult meg, melynek elnöke Czitrom András lett. Czitrom Andrást a sportág egyik alapítójának tekintenek, aki Svédországban él magyar származású [9] [14]. A Nemzetközi Floorball Szövetséget (IFF) a Cseh Köztársaság, Finnország és Svédország floorball szövetségei szervezték. Jelenleg az IFF 74 ország képviselteti magát, és világszerte 4929 klub és több mint 361666 engedéllyel rendelkező játékos múködik. A SportAccord 
(korábban GAISF néven ismert) rendes tagja és a Nemzetközi Olimpiai Bizottság (NOB) által elismert sportág. Az IFF évente megrendezi a Bajnokok Kupáját (CC), az Euro Floorball Kupa (EFC) és a Floorball Világbajnokságot (WFC). A WFC-ket páros években játsszák a férfiak és az U19 nők, a páratlan években a nők és az U19 férfiak [7]. Az IFF szorosabb kapcsolatot ápol a 10 legfontosabb floorball országgal és azok marketing vezetőivel. Például közösen készítik el a nemzetközi szövetség marketing tervét is. Az első tíz floorball ország: Csehország, Dánia, Finnország, Németország, Lettország, Norvégia, Lengyelország, Szlovákia, Svédország és Svájc.

Floorballt nem csak regisztrált játékosok játszanak. Svédországban, ahol a legtöbb regisztrált játékos és és közel 10 millió ember hazája, 2014-ben, fél millió lakos játszott rendszeresen floorballt az iskolákban, a különböző szövetségekben és a munkahelyeken, azaz a népesség körülbelül 5,2\% -a floorballozott valamilyen szinten [22]. Hazánkban még kevésbé népszerű a játék, de egyre több szakember, testnevelő vonja be hétköznapi testnevelés órákba.

\subsection{Floorball Magyarországon}

Magyarországon 1989-ben palánklabda néven jelent meg a sportág és ezen a néven alakult az első szövetség is. 1997-ben jött létre a Magyar Floorball Szövetség (MFSZ). A sportág hazai népszerűsítésén fáradozik a szövetség, melynek versenysorozatai amatőr sportolóknak is szólnak. Jelenleg a nőknél 6 csapatos bajnokság működik, míg férfiaknál 3 osztályban 25 csapat versenyzik egymással [17].

Az MFSZ, mint szakszövetség hazánkban irányítja, szervezi és ellenőrzi a floorball sportágban folyó közhasznú tevékenységet, népszerűsíti, valamint fejleszti a sportágat. Képviseli a floorball sportágnak és tagjainak érdekeit, valamint részt vesz a nemzetközi sportszervezetek tevékenységében. Szervezi a hazai floorball tevékenységet a Nemzetközi Floorball Szövetség (IFF) elvárásainak megfelelően. A Szakszövetség fő feladatának tekinti a sportág megismertetését és népszerűsítését a fiatalabb korosztályok körében. A sportág alkalmas a gyermekek szabadidő hasznos eltöltésére, közösségfejlesztésre, sportos életvitelre nevelésre és ösztönzésre ezáltal részét képezheti az egészségre nevelő és szemléletformáló programoknak a közoktatásban [18].

A szakszövetség legfőbb szerve a közgyưlés, mely évente legalább egyszer ülésezik (1. ábra). A szakszövetség elnökségének öt tagja van, akik minden naptári év negyedében üléseznek. Az elnökséget öt évre választják. A Szakszövetség legfőbb tisztségviselője a Szakszövetség Elnöke. A versenybizottság elnöke és 4 tagja szervezi és felügyeli a hazai versenyrendszert. A titkárság végzi az adminisztrációs feladatokat a főtitkár vezetésével. 


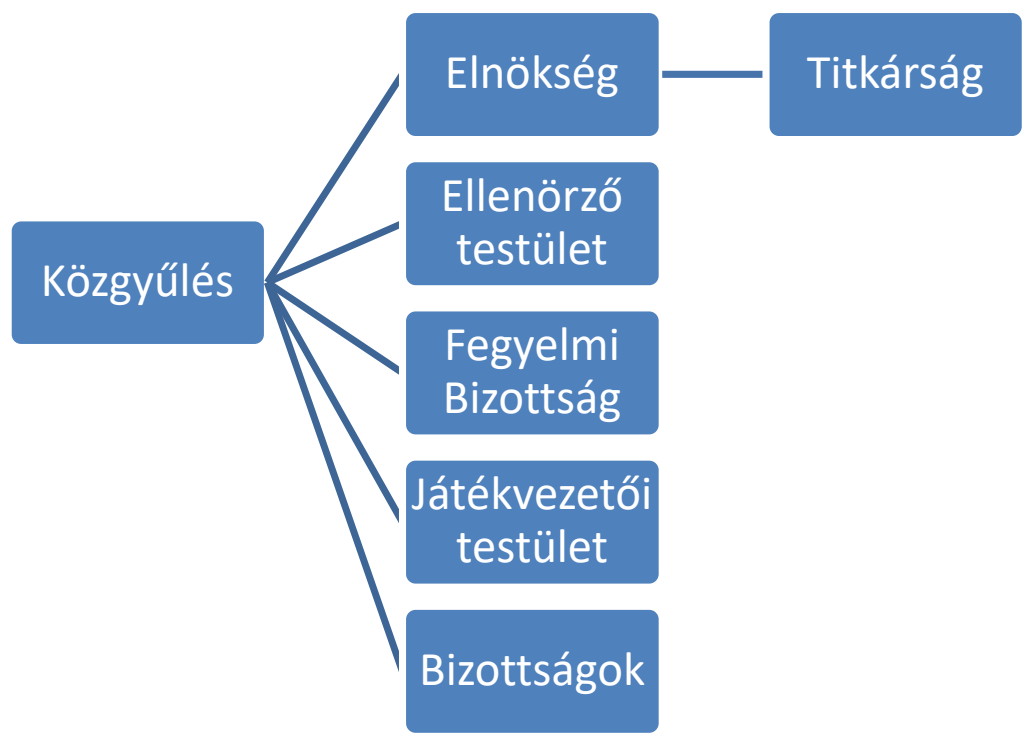

1. ábra. Az MFSZ Szervezeti felépitése

Forrás: saját szerkesztés [20] alapján, 2019

Az elnökség feladata meghívni a közgyűlés tagjait és egy hónappal az időpont előtt értesíteni a tagokat és az Ellenőrző Testület elnökét a helyszínről, dátumról és a napirendi pontokról. Az Ellenőrző Testületet (elnök+ 2 tag) a közgyúlés választja, melynek feladata a szakszövetség működésének, gazdálkodásának és vagyonkezelésének ellenőrzése [20].

A magyar floorball versenyrendszer lehet:

a./meghatározása szerint hivatásos, amatőr, vegyes (nyílt)

b./a részt vevők neme szerint férfi (fiú), női (leány), vegyes

c./a részt vevők kora szerint felnőtt, utánpótlás, öregfiúk

d./a pályaméret szerint nagypályás, unihoki, kispályás

e./lebonyolítása szerint bajnoki, kupa, egyéb.

A sportvállalkozás és sportegyesület floorball szakosztályai vehetnek részt vegyes bajnokságban. A bajnokságot minden évben július 1-től következő év június 30-ig tartják [21].

A floorball térhódítása több területen is várható a jövőben. Elsőként a mindennapos testnevelésbe történő beépítése, mivel alkalmas motorikus képességek fejlesztésére. Nevelési szempontból is hatékony lehet. A másik felhasználási területe a kiegészítő sportágként való alkalmazás, amely különböző csapatsportágak (kézilabda, kosárlabda, tenisz) edzésein alkalmazható rendszeresen [14].

\subsection{Passzív sportfogyasztás jellemzői}

A fogyasztói piacot, akik nem aktívan vesznek részt a sportszolgáltatásban két csoportra lehet osztani: akik a helyszínen veszik igénybe a sportszolgáltatást, mint nézők és médián keresztüli követőkről, fogyasztókról [11]. A sportfogyasztásnak több formáját is megkülönböztetünk, melyek közül passzív sportfogyasztásnak tekintjük azt is, ha részt veszünk egy mérkőzésen, mint néző. Neulinger [3] szerint az aktív és passzív sportfogyasztás skáláján a személyes mérkőzés látogatás középen helyezkedik el, ennél passzívabbnak tekinthető, aki például otthonról követi a mérkőzést. A szurkolói motivációs 
vizsgálatok a látvány csapatsportok közül főleg labdarúgással kapcsolatosak, a hazai szakirodalom száma még kevés [4].

Több hazai tanulmány szerint szurkolói szempontból a legnépszerűbb sportágak a látványcsapatsportágak közé tartozó labdarúgás és kézilabda [2] [26]. A labdarúgás a nemzetközi összehasonlításban alacsony színvonalon van, amely távol tartja a nézőket a helyszíni szurkolástól. Ezzel ellentétben, a kézilabdában hazánk csapatai az nemzetközi élvonalban versenyeznek. Az egyéni sportágak közül az úszás vonz a legtöbb nézőt a nézőtérre [2]. A nézők két nagy területen találkoznak a sportszolgáltatóval: a mérkőzésen, a szolgáltatás átadásakor illetve ezt megelőzően a korábbi reklámokban, interneten, TV-ben [8 alapján 5].

A hazai kutatások legnagyobb arányban a nézői sportfogyasztást motiváló tényezők vizsgálatával foglalkoznak [1] [4] [24] [25] [26].

\section{Anyag és módszer}

A primer kutatásunk során, hogy minél átfogóbb képet kapjunk az adott témáról kérdőíves felmérést és mélyinterjút is készítettünk a Debrecenben lassan 20 éve jelenlévő sportágról. A kérdőív 201812.10 és 2018.12.18 között volt elérhető. A kérdőív 14 kérdést foglalt magába, melyet két részre osztottunk. Az első rész olyan demográfiai adatokra vonatkoztak, mint a kitöltők neme, életkora, lakhelye, iskolai végzettsége, foglalkozása. A kérdéssor második része a floorballhoz kapcsolódott, hogy ismerik-e ezt a sportágat, voltak-e már kint mérkőzésen, mi vonzotta őket ki a mérkőzésre, vagy, hogy fizetnének-e belépőt, hogy megtekintsenek egy ilyen sporteseményt. Miután lezártuk a kérdéssort Microsoft Excell és Google kérdőív segítségével összesítettük és elemeztük a kapott adatokat.

A mélyinterjút Lánczi Andrással készítettük, aki a Debreceni Egyetemi Atlétika Club (DEAC) floorball szakosztályának vezetője és egyben a debreceni csapat tagja is hosszú ideje, valamint a nemzeti szövetségünkben is elismert személyről van szó, hiszen a szövetség elnökségi tagja. Igyekeztünk olyan interjú alanyt keresni, aki nagyon jól ismeri debreceni és országos szinten is a floorballt, és akinek van egy kis rálátása a minket körülvevő országok ezen, sportág helyzetére is. Lánczi úrral előzetes egyeztetés alapján, személyesen készült el az interjú, ezáltal a kérdőívünk eredményeivel is össze tudtuk hasonlítani a beszélgetésünk során az elhangzottakat.

\section{Eredmények}

Az eredményeket két alcím alatt ismertetjük. Elsőként a kérdőív eredményeit elemezzük, majd második fejezetben az interjú válaszait összevetjük a kérdőívben kapott eredményekkel.

\subsection{A passzív sportfogyasztók vizsgálatának eredményei}

A kérdőívet összesen 153 fő töltötte ki, melyből 96 fő férfi és 57 fő nő volt. Ezek az értékek azt mutatják, hogy a válaszadók, több mint a fele, pontosabban $62,7 \%$ férfi volt (2. ábra). 


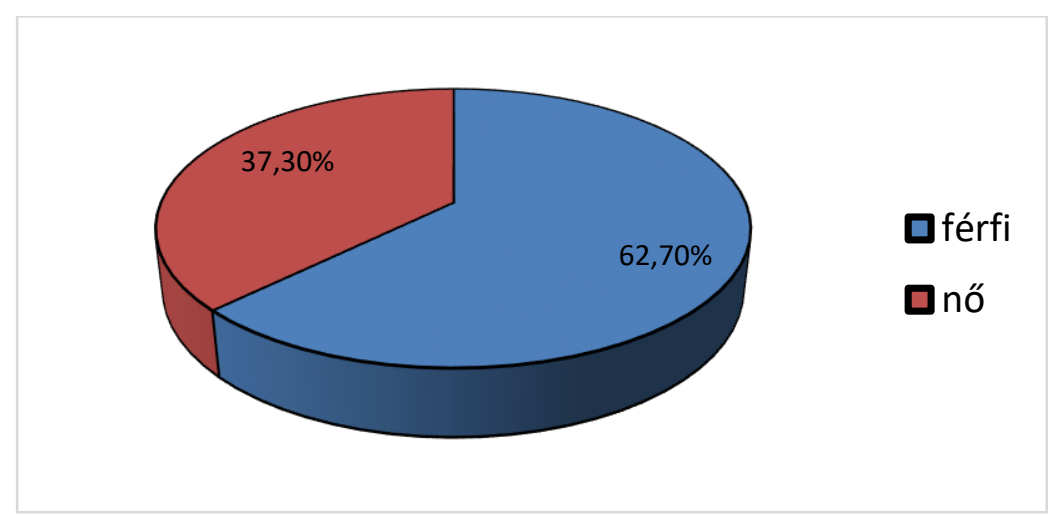

2. ábra. A válaszadók nemek szerinti eloszlása (\%)

Forrás: Saját kutatás és szerkesztés, 2020

Általánosságban megfigyelhető, hogy férfitársadalmat, jobban érdekli ez a sportág is, mint a nőket.

A 3. ábrán a válaszadók életkorának az eloszlását figyelhetjük meg. A 18 év alattiak a válaszadók 7,2\%át teszik ki (11fö), míg a 45 év felettiek 12,4\%át (19fő). Közel azonos létszámmal jelentek meg a 26 és 35 év közöttiek (13,7\% azaz 21 fő) és a 36 és 45 év közöttiek (11,1\% azaz 17 fő).

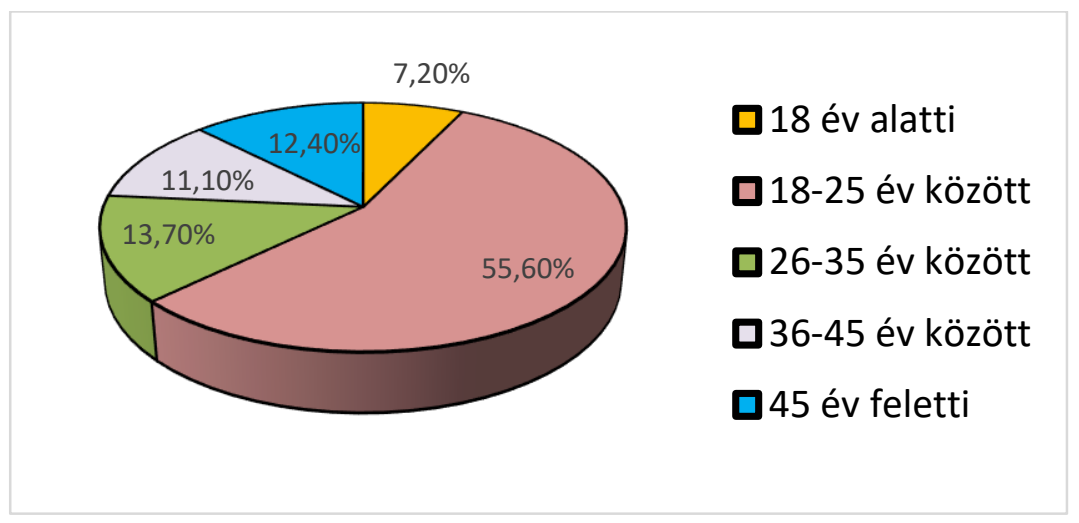

3. ábra: A kitöltők életkorának a megoszlása százalékos arányban

Forrás: Saját kutatás és szerkesztés, 2020

A 18 és 25 év közöttiek voltak a legtöbben a kitöltők között, ők a diagram 55,6\%-át tették ki, ami 85 főt jelent. Ez az arány nem annyira meglepő, mivel fiatal a sportág és ez a korosztály találkozhatott először szervezett keretek között hazánkban. A 96 férfi kitöltő közül 55 fő, míg 57 női válaszadó közül 30 fő képviselte a 18 és 25 év közötti korosztályt. Ebből is látszik, hogy mindkét nem ezen, korosztályát érdekli, vagy érdeklődik a floorball iránt, mindazonáltal ne felejtsük el megemlíteni, hogy az idősebb korosztálynak nem kedvez a kérdőívezés online formája.

A 4. ábrán a megkérdezettek iskolai végzettsége látható százalékos arányban. Az általános iskola 8 osztályát végzettek száma 16 fő, szakközépiskolát végzők száma 44 fő, a gimnáziumban végeztek pedig 51 fővel képviselték magukat. 


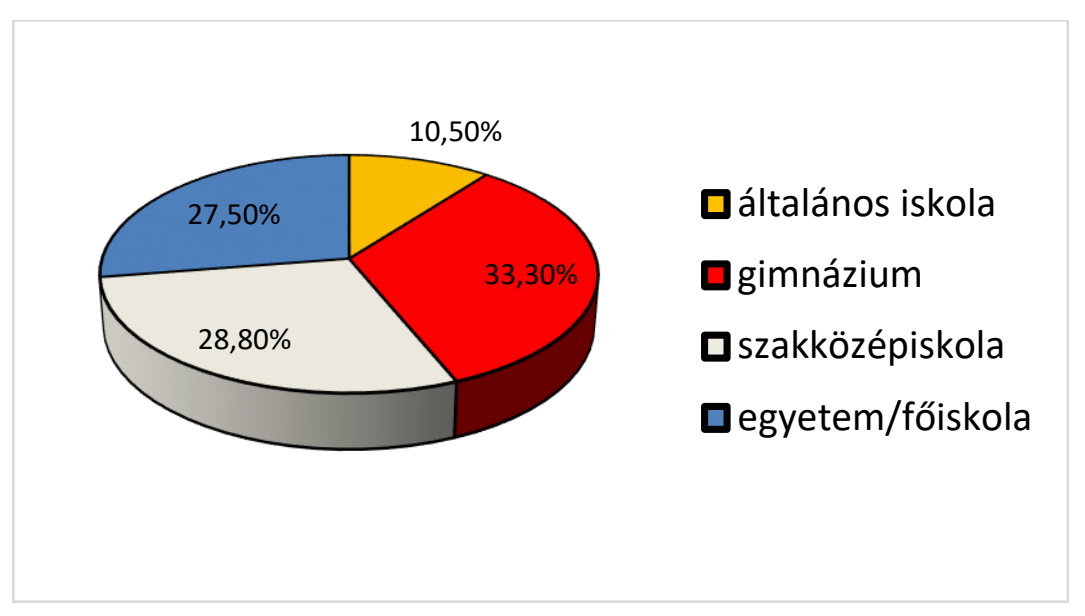

4. ábra. A kérdezettek iskolai végzettsége (\%)

Forrás: Saját kutatás és szerkesztés, 2020

Az egyetemi vagy főiskolai végzettséggel rendelkezők száma 42 fő. A gimnáziumi, a szakközépiskolai és az egyetemi vagy főiskolai végzettséggel rendelkezők száma közel azonos, ebből is látszik, hogy a megkérdezettek személyek elég széles skálát lefednek.

A kérdőívben szerepelt a kitöltők foglalkozására irányuló kérdés is (5.ábra).

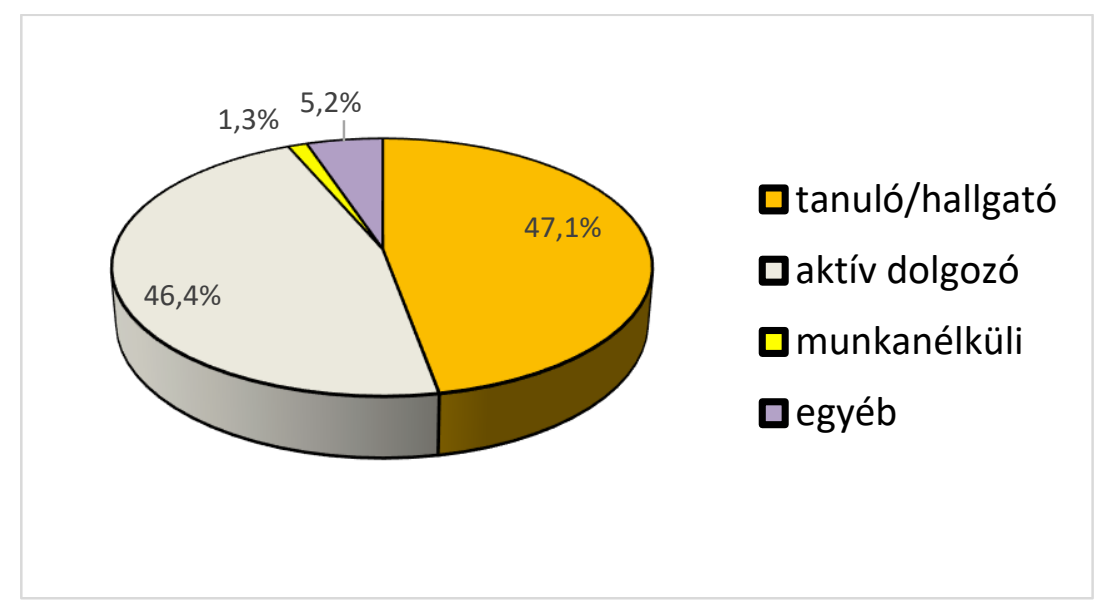

5. ábra. A válaszadók foglalkozása (\%)

Forrás: Saját kutatás és szerkesztés, 2020

Ezen kérdés alapján megállapítottuk, hogy a tanulók/hallgatók aránya a legnagyobb (47,1\%) ez 72 főt jelent. Az 57 nőből 25 fő tanuló vagy hallgató, míg a 96 férfi közül 47 fő az, aki szintén tanuló vagy hallgató. A második legnagyobb csoport az aktív dolgozók csoportja, akik 46,4\%-al (71 fó). Ez a 71 fő nemek szerint úgy alakult, hogy 44 férfi és 27 nő tartozott ebbe a kategóriába. Az uraknál 3-mal többen vannak azok, akik még tanulnak, a hölgyeknél viszont 2-vel többen tartoztak az aktív dolgozó kategóriába. A következő kategória a munkanélkülieké (1,3\%) akik 2 főt tesznek ki. Egy 18 év alatti és egy 25 és 35 év közötti férfi kitöltök alkották ezt a csoportot. Továbbá megjelöltük még egy egyéb 
kategóriát, ez alatt a nyugdíjasakat és gyesen/gyeden lévőket értettük Ők 8 főt tettek ki, ami 5,2\%-ot jelentett.

A következő ábrán az látható, hogy az emberek hány százaléka hallott-e már erről a sportágról, hiszen valljuk be, nem egy népszerű játékról beszélünk világszerte sem. Azonban, ahogy látszik a képen is a kitöltők 96,7\%-a (148 fó) hallott már a floorballról (6. ábra).

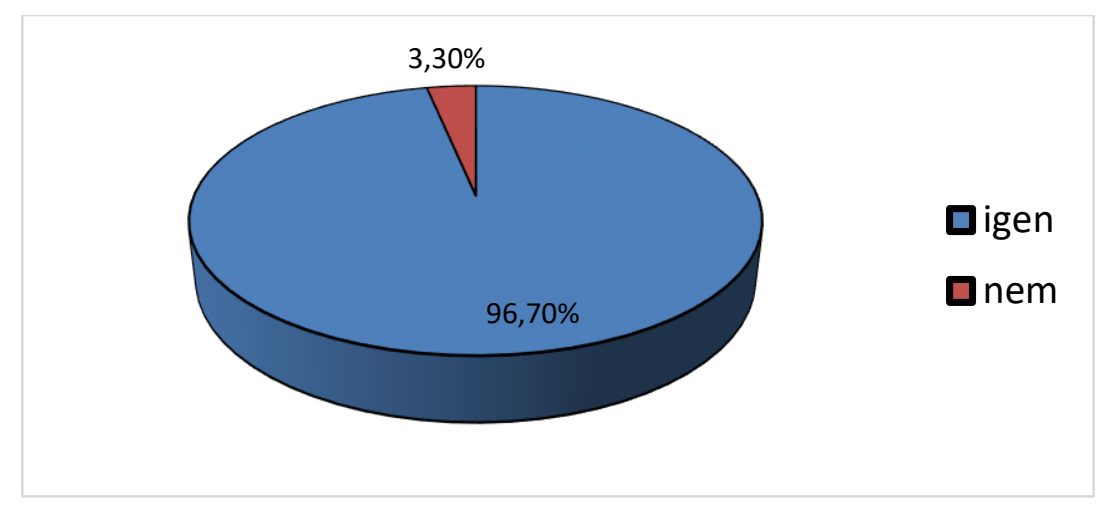

6. ábra. A floorballról, mint sportágról hallottak száma (\%)

Forrás: Saját kutatás és szerkesztés, 2020

Csupán a válaszadók 3,3\%-a (5 fő) nem hallott erről a dinamikus, fejlődő sportágról. Egy 18-25 év közötti gimnáziumi végzettséggel rendelkező férfi, egy 45 év fölötti egyetemi vagy főiskolai végzettséggel rendelkező férfi, egy 18 év alatti még gimnáziumi tanulmányokat folytató fiú, egy 25 és 35 év közötti egyetemi/főiskolai végzettséggel rendelkező férfi. Az 57 női kitöltő közül csupán egyetlen egy olyan hölgy volt, aki nem hallott erről a sportágról, Ő a kitöltők 18 és 25 év közötti gimnáziumi végzettséggel rendelkezők csoportját erősíti.

Mivel egy kevésbé ismert sportágról van szó, ezért fontosnak tartottuk megkérdezni, azt, hogy aki hallottak már erről a sportágról, ők honnan értesültek róla. A válaszlehetőségek között volt az interneten, a TV-ben, az újságban, vagy a rádióban hallotta vagy látta és az általános vagy középiskolában találkozott vele (7. ábra). A kitöltők többsége 42,5\%-a már az általános iskolában megismerkedett a sportággal, ami számokban kifejezve 65 főt jelent. A második legnagyobb csoport az egyéb kategória, amely azokat a válaszadókat jelenti, akik az egyetemen vagy baráttól, családtagtól hallottak erről a sportágról először. Ők a diagram 31,4\%-át teszik ki, ami 48 főt jelent. Őket követik azoknak az embereknek a csoportja, akik a középiskolában ismerkedtek meg ezzel a csapatsporttal. Ők a kitöltők 16,3\%-át jelentik, ami 25 főt jelent. A floorball egyik legfontosabb marketing eszköze a fiatalok és a játékosok és a követők közötti közösségi média interakció. Lehetővé teszi ingyenes és / vagy olcsó marketing csatornákat. A videó és a szociális média tartalmának megnézésekor minél több videoklipet és élő közvetítést érhetünk el a játékokból, annál nagyobb a lehetősége a sport fogyasztásának [22]. A vizsgálatban résztvevők közül kevesen voltak azok, akik az interneten látták először ezt a sportágat. Ők 10 fővel képviseltetik magukat, ami az egészhez nézve 6,5\%-ot jelent. A következő, ötödik csoport azok, akik a TV-ben találkoztak a floorballal, ők 2,6\%-ot tesznek ki, ami 4 főt jelentett. 


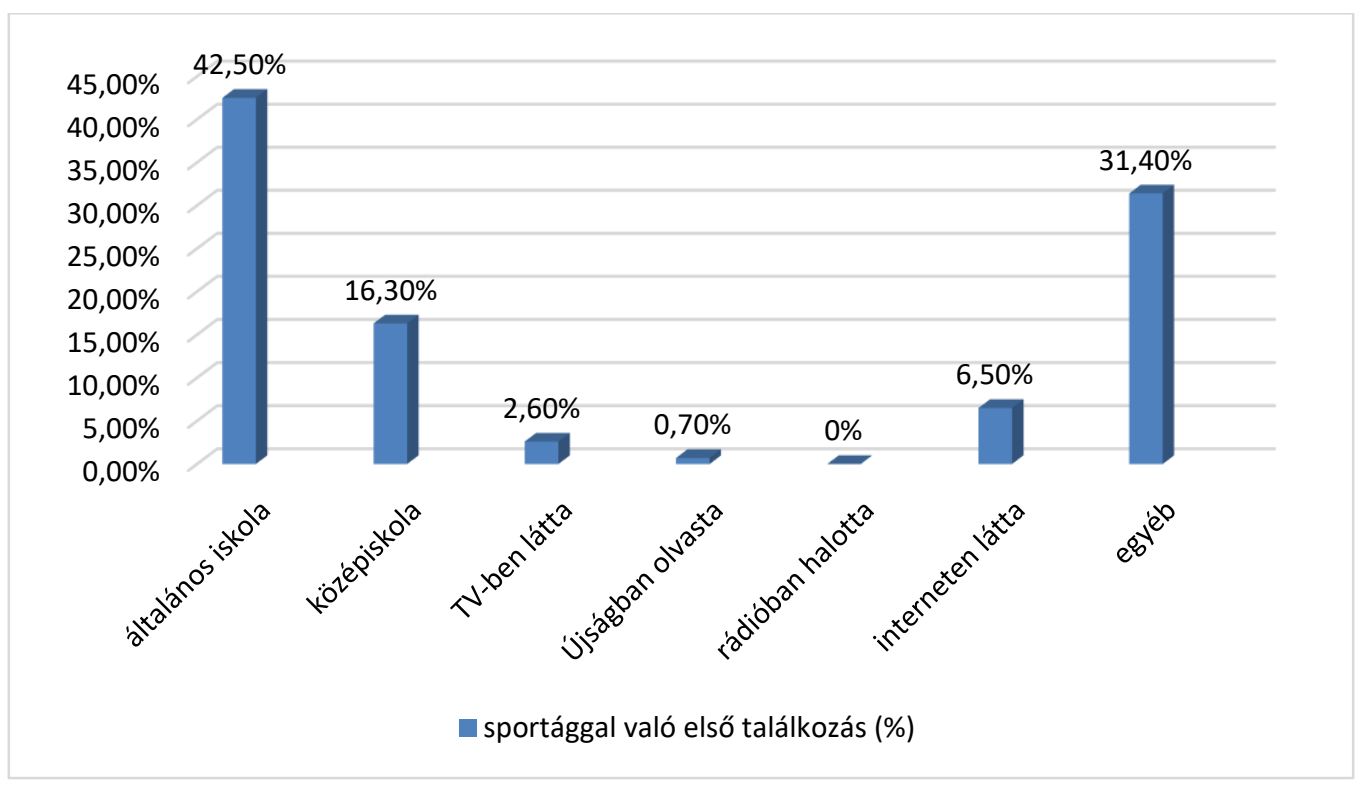

\section{7. ábra. A sportággal való első találkozás \%}

Forrás: Saját kutatás és szerkesztés, 2020

Végül, de nem utolsó sorban volt egy ember, aki újságban olvasott először erről a játékról. Meglepő módon, nem érkezett a rádióra szavazat, ami azt jelenti, hogy nem volt olyan személy, aki a rádión keresztül értesült volna erről a labdajátékról. Az országban nagyon ritkán jelenik meg ez a sportág az újságokban. Tv-ben vagy rádióban pedig még kevesebbszer szerepel. Debrecenben egy kicsivel jobb a helyzet, a Campus rádióban rendszeresen szerepel illetve a Rádió 1 is szokott híreket közölni a Deac Floorball csapatáról. Ezeken túl a helyi televíziós csatornában is többször sikerült szerepelnünk.

A következő kérdéssel arra kerestük a választ, hogy a kitöltők részt vettek-e már, mint néző egy floorball mérkőzésen (8. ábra).

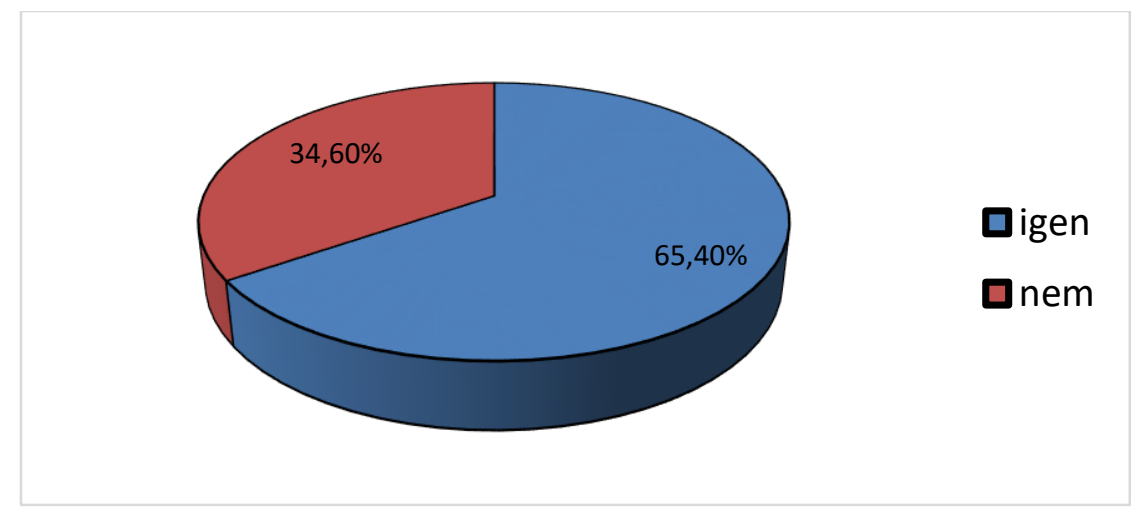

8. ábra. Látott-e már élőben floorball mérkőzést? (\%)

Forrás: Saját kutatás és szerkesztés, 2020

A kitöltők többsége már volt jelen személyesen egy ilyen eseményben. Számokban kifejezve a válaszadók 65,4\%-a, ami kereken 100 fót jelent.

A női válaszadók több mint a fele már látott élőben floorball mérkőzést. Az 57 női kitöltő közül, csupán 26 olyan hölgy volt, aki még nem volt kint személyesen egy ilyen eseménye. Míg a 96 férfi kitöltő közül 
27 olyan volt, aki még nem látogatott ki egy mérkőzésre sem. Ezekből az adatokból következtethetünk arra, hogy ez a dinamikus sportág, a férfitársadalmat jobban vonzza, mert amíg a nőknek majdnem a fele nem látott floorball mérkőzést, addig a férfi kitöltőknél ez az arány az egyharmadot sem éri el.

A következő ábrán arra kapunk választ, hogy a válaszadónk kivel látogatna ki szívesen megtekinteni az általam választott sportág egy mérkőzését. A kitöltők többsége 107, fő baráti társaságban szeretne elmenni a rendezvényre, 40 fő pedig a családot preferálta a barátok előtt, 6 fő pedig inkább egyedül szeretné eltölteni ezt a kellemes időtöltést (9. ábra).

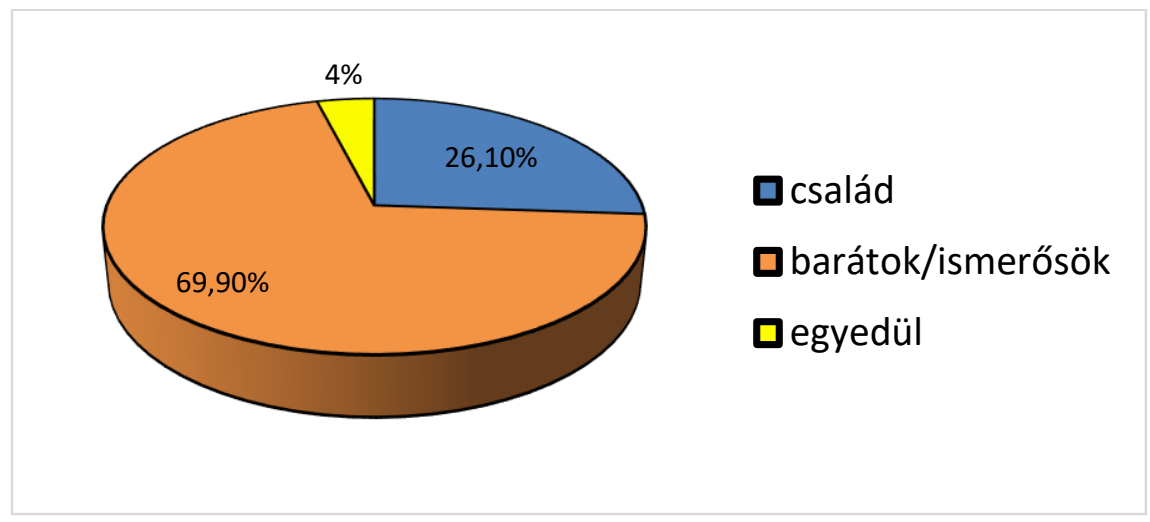

9. ábra. Kivel látogatna ki egy mérkőzésre?(\%)

Forrás: Saját kutatás és szerkesztés, 2020

Nemi lebontásban úgy alakul ez, hogy a férfiak közül 71-en tekintenék meg barátokkal vagy ismerősökkel a mérkőzést, míg az 57 hölgy közül 36 fő. Tehát kijelenthetjük, hogy mindkét nem többsége inkább a baráti körével látogatna ki. Családdal összesen 40 fő tekintené meg a mérkőzést, ez a 40 fő családiasan eloszlik, mindkét nem 20-20 főt ad ebbe a kategóriába. A férfiak közül 5 ember az, aki inkább egyedül tekintené meg a mérkőzést, míg a nőknél mindösszesen ez a szám csupán 1.

Külön kérdésben foglalkoztunk azzal, hogy, akik kilátogattak már egy mérkőzésre is, hogy mi vonzotta ki őket. A válaszok közül több lehetőséget is lehetett választani. A kitöltők közül legtöbben a sportág szeretete miatt látogat ki floorball mérkőzésre. Ők a 153 válaszadó 34\%-át jelenti (52fő). Második csoport, az olyan emberek csoportja, akik a játékosokkal ápolt viszony miatt mennek ki. Gondolok itt ez alatt barátra, barátnőre, testvérre. Ezek az emberek az egésznek a 22,9\%-át teszik ki (10. ábra). 


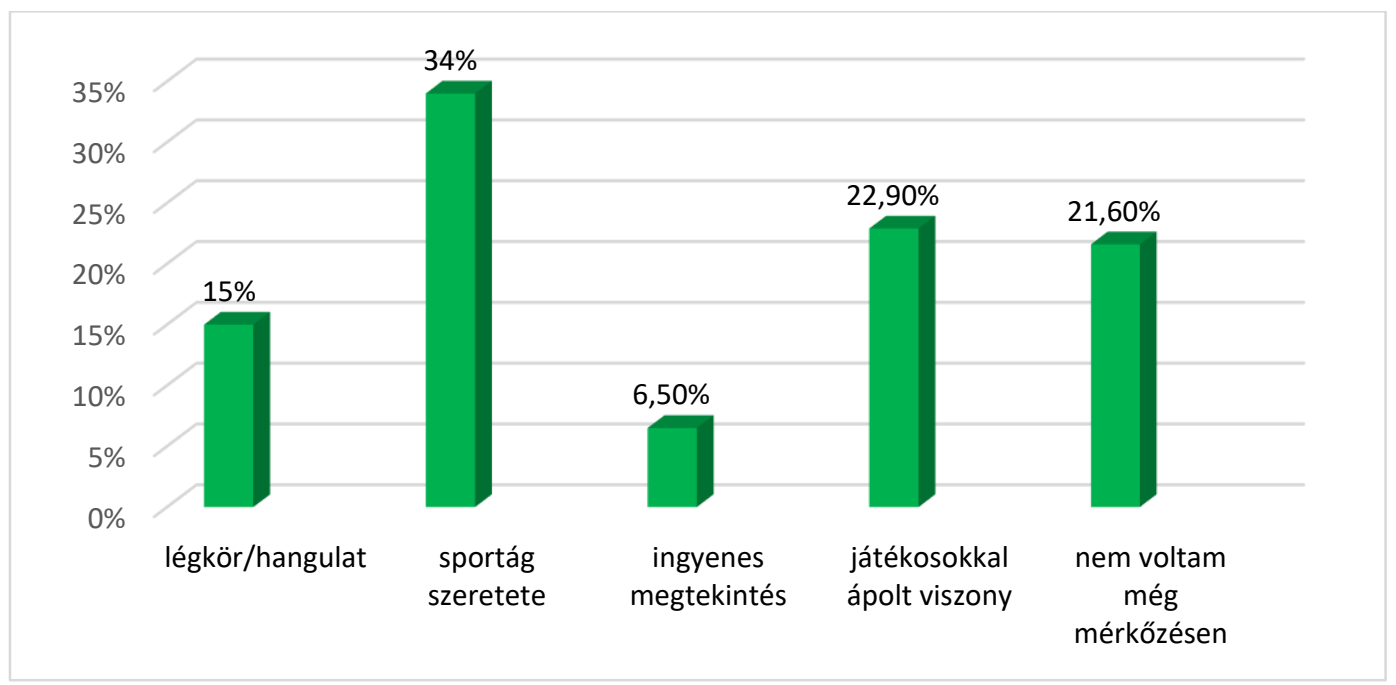

10. ábra. Mi vonzotta ki a mérkőzésre? (\%)

Forrás: Saját kutatás és szerkesztés, 2020

Utánuk következnek azok az emberek, akik még nem voltak kint mérkőzésen 21,6\%-al. A következő csoport a légkör és a hangulat miatt kilátogató emberek, ők 15\%-al vannak jelen. Az utolsó csoport pedig az ingyenes megtekintés lehetősége miatt látogattak ki. Érdekes módon Ők vannak a legkevesebben, mindösszesen csak 10 fővel képviseltetik magukat. Ez a 10 fő nemek szerint úgy alakult, hogy 5 férfit vonz és 5 hölgyet az ingyenes megtekinthetősége a sportágnak.

Mivel itthon egy floorball mérkőzés megtekintéséért sehol nem kérnek belépődíjat, ezért kíváncsi voltam, hogy, ha ezen túl fizetni kellene, hogy megtekintsenek egy párharcot, úgy is eljönnének-e a nézők. Szerencsére, ahogy az ábrán is látszik, majdnem a válaszadók fele, egészen pontosan 46,4\%-uk (ami számokban kifejezve 71 főt jelent) hajlandó lenne belépőt fizetni (11. ábra).

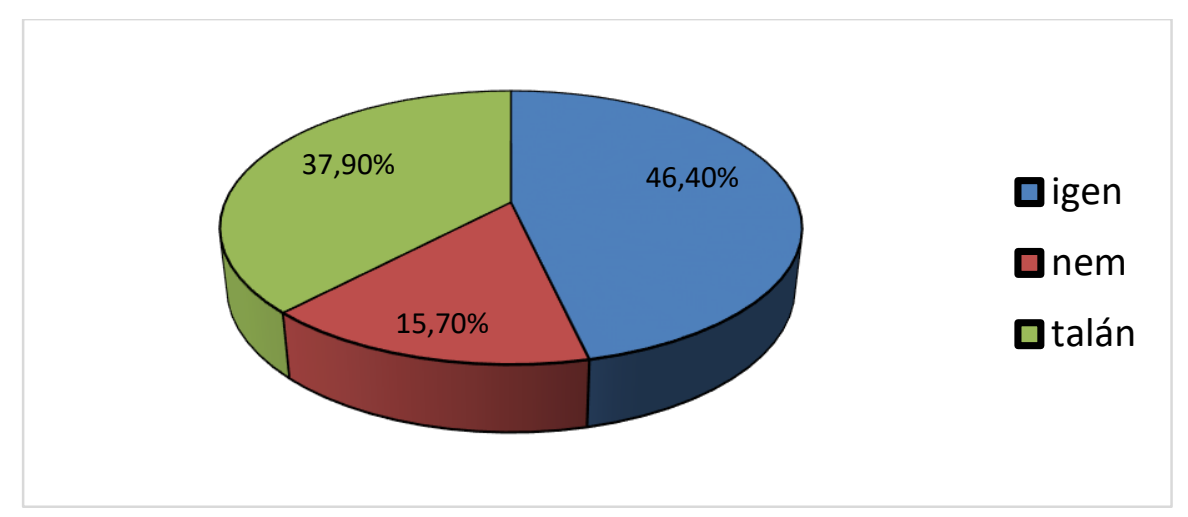

11. ábra. Fizetésre való hajlandóság (\%)

Forrás: Saját kutatás és szerkesztés, 2020

Az ábra 37,9\%-át (58 fő) adják ki azok, akik talán fizetnének belépődíjat egy ilyen mérkőzésre. Az 58 fő közül, viszont 17 fő, nem volt látott még floorball mérkőzést, ezért valószínűsíthető, hogy azért bizonytalan a válaszuk, mert nem tudják, hogy milyen élményekkel gazdagodnának a pénzükért cserébe. 


\subsection{A DEAC Floorball szakosztályának vezetőjével készített interjú eredményei}

Az interjút Lánczi Andrással készítettük, aki a Debreceni Egyetem Atlétikai Club floorball szakosztályának a vezetője és a MFSZ elnökségi tagja, így pontos rálátása van a magyar floorball helyzetére, népszerűségére, versenyrendszerére. Az interjú alany elmondta, hogy a magyar floorball életben jelenleg van egy minimális visszalépés, ami a csapatok számát jelenti. A férfi oldalon aránylag stabil állandó résztvevők vannak. Volt olyan bajnoki évad, amikor 12 csapatos első osztály volt, 10 csapatos másodosztály és szintén 10 csapatos harmadosztály. Most ehhez képest 8 csapatos első osztály, 6 csapatos másodosztály és 12 csapatos harmadosztály van a 2018/2019-es szezonban. A női mezőnyben jelentősebb a visszalépés, mert korábban a női bajnokság is sokkal több szereplős volt, míg most eljutottunk odáig, hogy ebben a szezonban négy csapat vesz részt a női első osztály küzdelmeiben. Emiatt itt is a női első osztályban a jelenlegi férfi harmadosztályához hasonlóan játéknapokat rendeznek. Ez annak köszönhető, hogy sokkal kevesebb igazolt játékos van, mint régebben. A Magyar Floorball Szövetség áltál megosztott adatok alapján, majdnem 9000 ember játszik floorballt ma hazánkban. Ebbe a 9000 főben beletartoznak azok is akik, csak az iskolai testnevelés órán találkoznak ezzel a sportággal vagy csak a Diák Olimpián vagy az olyan idősebbek, akik csak hobbiból eljárnak baráti társasággal játszani. Ebből az igazolt sportolók száma csupán kb. 700 fő. Ez azt jelenti, hogy a floorballozók közül kevesebb, mint a 10\%-a igazolt játékos. Lánczi András szerint a legnehezebb feladat ebben van, hogy ebből a 9000 létszámból minél több ember kerüljön be a versenyzők száma közé. Azt is elmondta, hogy nem csak a gyerekek inspirálása lenne a cél, hogy be tudják őket vonzani a sportágba, hanem a felnőtteket is. Hiszen, ha megnézzük a Diák Olimpia versenyszámait, akkor láthatjuk, hogy az egyik legnépszerűbb közülük a kispályás floorball. De sajnos a legtöbb gyerek itt megáll, hiszen azt láthatjuk, hogy nem sok településen van floorball egyesület és a gyerekeknek nincs lehetősége versenyszerűen űzni a sportágat és sok fiatal tehetség itt veszik el. Szerinte itt kéne egy nagy áttörést elérni azzal, hogy be kéne vonzani a sportágba sok lelkes szülőt és sportvezetőt, akik vállalják azt, hogy versenyeztetnek csapatot. A gyerekeket is sokkal nehezebb mozgásra ösztönözni, mint 20-30 évvel ezelőtt, elég komoly versenytársai okoztak a testmozgásnak és a gyerekek akkor fognak szívesen sportolni legyen az bármilyen sport, ha ez által ők is valami féle pluszt kapnak, valamilyen olyan élménnyel gazdagodnak, amit egy videó játék vagy egy közösségi médián történő cselekvés nem tud visszaadni.

2003-tól lehetett Debrecenben egyesületi keretek között játszani ezt a sportágat. Ekkor alakult meg a DFSE (Debreceni Floorball Sport Egyesület). Az elmúlt 16 évben mindösszesen két olyan szezon volt, amikor nem vett részt a bajnokságban a debreceni együttes. Igaz voltak szintbeli különbségek ebben az időszakban. 2004-2005-ös szezonban a csapat az OB 3-ban indult, érdekes módon ott csak a harmadik helyet sikerült megszereznie a csapatnak, de így is látták a potenciált szövetség részéről a csapatban, így a 2005-2006-os bajnokságot már az OB 2-ben kezdték meg, ami egy nagyon jó év volt, mert veretlenül nyerte meg a debreceni csapat, illetve a Magyar Kupában a döntőig jutott. Így a 2006-2007-es szezonban az OB 1-ben indult a csapat, amit újoncként sikerült megnyernie, amire se azelótt se azután nem volt még példa. 
Az interjú alanyunk nyilatkozott, hogy milyen jelenleg a válogatott helyzete és milyen helyet foglal el a csapat világranglistán és, hogy milyen egy világbajnokság versenyrendszere. Magyarországon van jelenleg felnőtt férfi, felnőtt női, valamint férfi u19-es válogatott. Kétévente rendeznek a floorballban világbajnokságot. A világbajnokságon a férfi és női mezőnyben egyaránt 16 csapat szerepel, az u19-es korosztályban meg vannak még a divíziónkénti rangsorolás. Az első világbajnokságon a magyar csapat csak a 10. helyet tudta megszerezni a 10 csapatból. A következő években, amíg a felnőtt mezőnyben is megvoltak a divíziós elosztások akkor a csapat rendszerint a B divízióban szerepelt, ez világszinten akkor a 12.-16. hely közötti mezőnyt jelentett. Sajnos ez a pozíció évek óta stagnál. A megváltozott világbajnoki selejtezők lebonyolítása miatt 2012-ben sikerült kijutnunk az „A" csoportos világbajnokságra Petri Touminen irányításával, aki előtte a debreceni csapat edzője volt. Jelenleg egy világbajnoki kvalifikációs rendszer úgy néz ki, hogy van több selejtező csoport, ami inkább egy tornára hasonlít. Nincs elnyújtva, mint egy labdarúgó kvalifikációs rendszer, költséghatékonyság miatt, hanem egy héten keresztül egymást követő napokon játszanak egymással az egy csoporton belüli csapatok, egy csoportban 6 csapat szerepel. Európában négy selejtező csoport volt, Amerikában kettő és Ázsia meg Ausztrália és Óceánia egy föderációban szerepel ezért ott is csak kettő selejtező csoport volt. Európa kapja a legtöbb helyet a vb-n, Amerika csupán csak egyet, Ázsia és Ausztrália négyet. Elmondása szerint reális esély van rá, hogy a következő világeseményen ott legyen a magyar csapat, de tudni kell, hogy ez nem egy elvárás, mert valamilyen szinten bravúr kell hozzá, hogy ez sikerüljön. Minden meccsen a száz százalékot kellene nyújtani és a fontos lélektani pillanatokban jó döntéseket kell meghozni. A mostani selejtező sorozatban is úgy volt, hogy egy ki-ki meccset veszítettünk el és egy már megnyert meccset bukott el a csapat a vége előtt nem sokkal döntetlenre.

Az interjú válaszait összevettük a kérdőív eredményeivel is. Az interjú alany szerint minél fiatalabb a válaszadó, annál nagyobb a valószínúsége, hogy találkozott már a sportággal, de sajnos az emberek többsége valószínű, hogy nem tudja, hogy létezik a floorball. Ellentétben a kérdőív eredményeivel, hiszen az öt főből, aki még nem hallott a sportágról csupán csak egy idősebb, 45 év feletti egyetemi végzettséggel rendelkező férfi volt, a többi válaszadó egy 18 év alatti fiú, egy-egy 18 és 25 év közötti férfi, illetve hölgy és egy 25 és 35 év közötti aktív dolgozó férfi volt.

Az interjú válasza szerint az általános iskolákban van a legnagyobb esély, hogy találkozott a sportággal az átlag ember, amely adódik a floorball diákolimpia népszerűségéből és a testnevelő tanárok is szívesen használtatják az ütőket a diákokkal. A kérdőív válaszai is alátámasztják azt, amit a szakosztályvezető mondott, hiszen toronymagasan ez a válaszlehetőség kapta a legtöbb szavazatot a maga 42,5\%-ával. Arra a kérdésre, hogy az emberek hány százaléka látott már floorball mérkőzést hazánkban szakosztályvezető szerint, sajnos az emberek többsége biztosan nem látott még élőben mérkőzést. Becslése szerint a magyar lakosság mintegy 8-10\% látott csak élőben mérkőzést. A kérdőív válaszolóinak 65,4\%-a volt, míg 34,6\%- a nem vett részt floorball mérkőzésen. A válaszok közötti nagy eltérés adódhat abból, hogy környezetünkben átlagon felüli az elérhetősége a sportágnak és akik kitöltötték a kérdőívet már nagy részben kapcsolódtak a sportághoz valamilyen fogyasztói szinten.

Megkérdeztük, hogy embereket érdekli annyira a floorball, hogy kimenjenek-e megnézni egy meccset? Erre a kérdésre azt válaszolta, hogy szerinte a lakosság olyan 20-25\%-a vevő lenne rá, hogy megnézzen egy-egy mérkőzést élőben is. Sajnos hozzájuk viszont nem vagy csak nagyon nehezen jutnak el az 
egyesületek. Itt a kérdőív megint teljesen eltér attól, ami a válaszra érkezett, hiszen a válaszadók 78,4\%a igennel válaszolt, hogy el jönne megnézni egy mérkőzést és még voltak azok a kik a talán válaszlehetőségre szavaztak 13,7\%-al. Azok közül, akik erre szavaztak, már csak a fele eljön, az azt jelenti, hogy az emberek jelentős részét a válaszadók 85\%-át ösztönözni lehetne arra, hogy kilátogasson a sportág egy mérkőzésére.

Az interjúban megkérdeztük, hogy szerinte az emberek hajlandóak-e belépődíjat fizetni egy adott floorball mérkőzésre. Erre a kérdésre nagyon rövid és határozott választ kaptunk, ami szerint az emberek 35\%-a, ha úgy van fizetne belépő díjat és a többi 65\% nem és akik fizetnének ők is maximum 1000 Ft-ot. Ezzel szemben a kérdőív mást mutatott. Az emberek 46,4\%-a fizetne belépődíjat és csupán csak 15,7\% mondta azt a megkérdezettek közül, hogy határozottan nem fizetne ezért egy forintot sem, a többi ember tartózkodott vagyis talánnal válaszolt.

\section{Következtetések}

A floorball egy viszonylag új beltéri sport, amely gyorsan népszerűvé vált. Három 20 perces harmadban játszanak egy $40 \times 20$ m-es pályán, amelyet egy 0,5 m magas palánk vesz körül. Minden csapatból hat játékos vesz részt az aktív játékban, beleértve a kapust is. A mezőny játékosok műanyag labdát ütnek szénből és kompozit anyagból készült ütőkkel. A hazai versenysportban több, mint húsz éve van jelen, legnagyobb bázisa az általános iskolás korúak között van.

A kutatás szerint a megkérdezettektöbb, mint 95\%-a halott a sportágról legnagyobb számban már az általános iskolai éveik alatt. A kitöltők többsége $(65,4 \%)$ már volt floorball mérkőzésen, ahova legtöbben barátaikkal/ismerőseikkel látogattak ki. A kitöltők közül legtöbben a sportág szeretete miatt látogattak ki floorball mérkőzésre. A sportág népszerűsítése érdekében a feladat, hogy növeljük az amatőr sportolók létszámot, amit az iskolai szervezett órák emelésével tudjuk elérni. A sportág ha nagyobb figyelmet kapna médiában növekedne a passzív sportfogyasztók létszáma is.

\section{Köszönetnyilvánítás}

A publikáció elkészítését az EFOP-3.6.2-16-2017-00003 számú projekt támogatta. A projekt az Európai Unió támogatásával, az Európai Szociális Alap társfinanszírozásával valósult meg.

\section{Hivatkozások}

[1] A. Kajos, Gy. Prisztóka, R. Paic (2017): A nézőtéri sportfogyasztás motivációit mérő, magyar nyelvű „speed-h” skála validációja és néhány eredménye, Vezetéstudomány, Budapest Management review, XLVIII. évf. 2017.

[2] A. Kovács Antal, D. Paár, G. Elbert, Zs. Welker, M. Stocker, P. Ács (2015). A MAGYAR HÁZTARTÁSOK SPORTFOGYASZTÁSI SZOKÁSAINAK FELMÉRÉSE. Pécsi Tudományegyetem Egészségtudományi Kar, Pécs (ISBN 978-963-642-983-6) 
[3] Á. Neulinger (2007). Társas környezet és sportfogyasztás. A folyamatos megrősítést igénylő tanult fogyasztás (Doctoral dissertation, Budapesti Corvinus Egyetem).

[4] É. Bába B., R. Balogh, B. A. Bács, A. Molnár, V. Fenyves, A. Müller (2019). A PASSZíV SPORTFOGYASZTÁS MOTIVÁCIÓINAK VIZSGÁLATA A NEMEK TÜKRÉBEN. Economica, 10(1), 30-35.

[5] C. Lovelock (ed.) (1992): Managing services, Prentice Hall, second edition

[6] IFF, Iskolai Floorball Tanterv http://specialolympics.hu/portal/wpcontent/uploads/2017/11/IFF-Iskolai-Floorball-Tanterv.pdf 2019. október. 6

[7] IFF, registered floorball players https://floorball.sport/theiff/memberassociations/member-statistics/licensed-registered-players/ letöltés dátuma: 2020. február 10.

[8] F. Dénes (1998). A futball eladása a közönségnek. Marketing \& Menedzsment, 32(5), 59-63.

[9] J. Nagy (2011) Hogyan válasszak sportágat? SportVital Kiadó, Kossuth Kiadó, Budapest, p 767. (ISBN 978-963-08-0647-3)

[10] J. Vorup, M.T. Pedersen, P.S. Melcher, R. Dreier, J. Bangsbo (2017). Effect of floorball training on blood lipids, body composition, muscle strength, and functional capacity of elderly men. Scandinavian Journal of Medicine \& Science in Sports, 27(11), 1489-1499.

[11] András, K. (2004). A hivatásos labdarúgás piacai. Vezetéstudomány-Budapest Management Review, 35(klnsz.), 40-57.

[12] K. Pasanen, M. Rossi, J. Parkkari, P. Kannus, A. Heinonen, K. Tokola, G. Myklebust (2016). Low back pain in young basketball and floorball players. Clinical Journal of Sport Medicine, 26(5), 376-380.

[13] K. Pasanen, J. Hietamo, T. Vasankari, P. Kannus, A. Heinonen, U.M. Kujala, J. Parkkari (2018). Acute injuries in Finnish junior floorball league players. Journal of science and medicine in sport, 21(3), 268-273.

[14] L. Gallovits, L. Honfi, Gy. Kovács (2011): Sport A-tól Z-ig. Általános és különleges sportágak ismerete, Dialóg Campus

[15] M. Leppänen,, K. Pasanen, U.M. Kujala, T. Vasankari, P. Kannus, S. Äyrämö, J. Parkkari (2017). Stiff landings are associated with increased ACL injury risk in young female basketball and floorball players. The American journal of sports medicine, 45(2), 386-393.

[16] M. Leppänen, K. Pasanen, U.M. Kujala, J. Parkkari (2015). Overuse injuries in youth basketball and floorball. Open access journal of sports medicine, 6, 173.

[17] MFSZ http://www.hunfloorball.hu/ user/Floorball-Youth-Start-Up-Kit JAV.pdf letöltés dátuma: 2019. szeptember 30. 
[18] MFSZ alapszabályzat

http://www.hunfloorball.hu/ user/mfsz\%20alapszab\%C3\%A1ly\%202018.pdf letöltés dátuma: 2020. február 10.

[19] MFSZ játékszabályok http://hunfloorball.hu/ user/file/down/szabalyzat/Szabalykonyv\%20Aug2010\%20\%20valtozasokkal.pdf letöltés dátuma: 2020. február 9.

[20] MFSZ szervezeti felépítés http://www.hunfloorball.hu/szervezeti-felepites letöltés dátuma: 2020. február 10.

[21] MFSZ versenyszabályzat http://www.hunfloorball.hu/ user/mfsz\%20versenyszab\%C3\%A1lyzat\%202019.pdf letöltés dátuma: 2020. február 9.

[22] M. Nurminen (2017) Social media campaign for the International Floorball Federation in connection to The World Games. Haaga-Helia University of Applied Science, Sport and Leisure Management.

$\mathrm{p}$ 68. https://d3kfx7mdprc67r.cloudfront.net/2018/07/Nurminen Minna.pdf letöltés dátuma: 2019. szeptember 30.

[23] N. Szilágyi, Z. Petrovszki, P. Szablics Rekreáció II. - rekreációs játékok mozgásformák (ISBN 978-963-306-322-4)

[24] P. Váczi (2013) A 2013 évi madridi kézilabda férfi világbajnokság szurkolói kérdőíves felmérése, tapasztalatai. Az Eszterházy Károly Főiskola tudományos közleményei (Új sorozat 40. köt.). Tanulmányok a sporttudományok köréből. Testkultúra, sporttudomány= Acta Academiae Agriensis. Sectio Sport, 61-66.

[25] R. Balogh, R., É. Bába Bácsné (2019). Az MSCC szurkolói motivációs skála adaptálása egyetemi hallgatók KÖRÉBEN= Adaptation of MSCC Fan Motivation Scale in University Students. Studia Mundi-Economica, 6(1), 3-10.

[26] R. Balogh, A. Molnár, A. Müller, G.N. Szabados, É. Bácsné Bába (2019) A passzív sportfogyasztás vizsgálatának tapasztalataiból. Acta Carolus Robertus= Az Eszterházy Károly Egyetem Gyöngyösi Károly Róbert Campusának tudományos közleményei, 35-48.

[27] T. Bro, F. Ghosh (2017). Floorball-related eye injuries: The impact of protective eyewear. Scandinavian journal of medicine \& science in sports, 27(4), 430-434.

[28] T. Tervo, A Nordström (2014). Science of floorball: a systematic review. Open access journal of sports medicine, 5 , pp. 249-254.

[29] U. Tranaeus, E. Götesson, S. Werner (2016). Injury profile in swedish elite floorball: a prospective cohort study of 12 teams. Sports health, 8(3), 224-229. 